PRODUCTIVIDAD PRIMARIA EN EL GOLFO DE CALIFORNIA, CALCULADA A PARTIR DE LA RELACIÓN ENTRE IRRADIANCIA SUPERFICIAL Y CLOROFILA DE LA ZONA EUFÓTICA

\title{
PRIMARY PRODUCTIVITY IN THE GULF OF CALIFORNIA, CALCULATED FROM THE RELATIONSHIP BETWEEN SUPERFICIAL IRRADIANCE AND CHLOROPHYLL IN THE EUPHOTIC ZONE
}

\author{
José Eduardo Valdez-Holguín ${ }^{1,2}$ \\ Gilberto Gaxiola-Castro ${ }^{2}$ \\ Rafael Cervantes-Duarte ${ }^{2,3}$ • \\ ${ }^{1}$ Universidad de Sonora \\ Departamento de Investigaciones Científicas y Tecnológicas \\ Rosales y Niños Héroes $\mathrm{s} / \mathrm{n}$ \\ Hermosillo, Sonora \\ México \\ ${ }^{2}$ Centro de Investigación Científica y de Educación Superior de Ensenada \\ División de Oceanología \\ Apartado postal 2732 \\ Ensenada, BC \\ México \\ ${ }^{3}$ Centro Interdisciplinario de Ciencias Marinas \\ Apartado postal 592 \\ La Paz, BCS \\ México
}

Recibido en septiembre de 1994: aceptado en marzo de 1995

\section{RESUMEN}

La distribución vertical de clorofila $a$ en el golfo de California durante la primavera de 1992 , presentó un máximo superficial entre los 10 y $50 \mathrm{~m}$ de profundidad. La concentración promedio de clorofila $a$ superficial fue de $0.71 \mathrm{mg} \mathrm{m}^{-3}$. Esta concentración se relacionó linealmente con la clorofila $a$ integrada en la zona eufótica $\left(\mathrm{r}^{2}=0.31, \mathrm{p}<0.001\right)$ y en la primera profundidad óptica $\left(\mathrm{r}^{2}=0.56\right.$, $\mathrm{p}<0.001$ ), estimadas a partir de un modelo espectral. Las estimaciones de clorofila integrada en la zona eufótica presentaron los valores más altos en la región de las grandes islas $\left(62.76 \mathrm{mg} \mathrm{m}^{-2}\right)$. Con los valores calculados de clorofila integrada e irradiancia incidente se estimó la productividad de la columna de agua del golfo de California, a través del parámetro $\Psi^{*}$. Las estimaciones de productividad realizadas con diferentes valores de este parámetro son comparadas con mediciones de la productividad in situ hechas con el método del ${ }^{14} \mathrm{C}$ y estimaciones a partir de fluorescencia natural del fitoplancton. Los valores obtenidos se incrementaron de la región sur del área de estudio hacia la parte norte, y alcanzaron los máximos en las grandes islas. Se propone un valor de $\Psi_{p}{ }_{p}=0.039 \pm 0.017 \mathrm{~m}^{2}$ $(\mathrm{gCla})^{-1}$, para la primavera del golfo de California.

Palabras clave: clorofila, productividad primaria, golfo de California.

- Becario de la Comisión de Operación y Fomento de Actividades Académicas del Instituto Politécnico Nacional. 


\begin{abstract}
The vertical distribution of chlorophyll $a$ in the Gulf of California during the spring of 1992 showed a subsurface maxima between 10 and $50 \mathrm{~m}$ of depth. The average surface chlorophyll concentration was $0.71 \mathrm{mg} \mathrm{m}^{-3}$. It was linearly related to the integrated chlorophyll of the euphotic zone $\left(r^{2}=0.31, p<0.001\right)$ and in the first optical depth $\left(r^{2}=0.56, p<0.001\right)$, estimated from a spectral model. The highest values of the integrated chlorophyll of the euphotic zone were found at the region of the large islands $\left(62.76 \mathrm{mg} \mathrm{m}^{-2}\right)$. The calculated values of integrated chlorophyll and incident irradiance were used to estimate primary productivity in the water column of the Gulf of California, throughout the parameter $\Psi^{*}$. The predictions obtained with different values of this parameter were compared with measurements of primary productivity made in situ with the ${ }^{14} \mathrm{C}$ method and estimated with natural fluorescence. Productivity increased to the north, reaching maximum values at the large islands region. $\Psi_{\mathrm{p}}^{*}=0.039 \pm 0.017 \mathrm{~m}^{2}(\mathrm{gCl} a)^{-1}$ is proposed for spring in the Gulf of California.
\end{abstract}

Key words: chlorophyll, primary productivity, Gulf of California.

\section{INTRODUCCIÓN}

El golfo de California es un mar marginal del océano Pacífico con altas tasas de producción primaria (Zeitzchel, 1969; Gaxiola-Castro y Álvarez-Borrego, 1986; Valdez-Holguín y Lara-Lara, 1987), debido a los procesos físicos de mezcla que continuamente fertilizan con nutrientes la zona eufótica (Álvarez-Borrego y Lara-Lara, 1991). Round (1967) dividió el golfo en cuatro regiones, con base en la distribución de fitoplancton: región $\mathrm{I}$, al sur de la latitud $25^{\circ} \mathrm{N}$; región Il (central), entre los $25 \mathrm{y}$ $27^{\circ} \mathrm{N}$; región III (norte), entre los $27^{\circ} \mathrm{N}$ y las grandes islas (Ángel de la Guarda y Tiburón); y la región IV (interior), al norte de las grandes islas. La abundancia de fitoplancton se incrementa de la región I al interior y alcanza sus máximas abundancias en la región III. Sin embargo, actualmente no se puede establecer una variabilidad espacial de la productividad, ya que la información es escasa, con gran dominio de datos costeros.

Con el uso de la información proporcionada por sensores remotos como el Coastal Zone Color Scanner (CZCS), y en un futuro próximo por el Sea-viewing Wide Field-of-view Sensor (SeaWiFS), es posible obtener una distribución sinóptica (espacial y temporal) de la biomasa fitoplanctónica (pigmentos fotosintéticos). Aunque estos datos sólo proveen información de la primera profundidad óptica, el resto de la biomasa de la zona eufótica puede estimarse a partir de relaciones empíricas entre la clorofila

\section{INTRODUCTION}

The Gulf of California is a marginal sea of the Pacific Ocean with high rates of primary productivity (Zeitzchel, 1969; Gaxiola-Castro and Álvarez-Borrego, 1986; Valdez-Holguín and Lara-Lara, 1987), due to the physical mixing processes that continually fertilize the euphotic zone with nutrients (Álvarez-Borrego and Lara-Lara, 1991). Based on the distribution of the phytoplankton, Round (1967) divided the gulf into four regions: region I, south of latitude $25^{\circ} \mathrm{N}$; region II (central), between 25 and $27^{\circ} \mathrm{N}$; region III (northern), between $27^{\circ} \mathrm{N}$ and the large islands (Ángel de la Guarda and Tiburón); and region IV (interior), to the north of the large islands. Phytoplankton abundance increases from region I towards the interior, reaching maximum abundances in region III. However, spatial variability in the productivity cannot be established as yet, since information is scarce and dominated by coastal data.

Using information provided by remote sensors such as the Coastal Zone Color Scanner (CZCS), and in the near future by Sea-viewing Wide Field-of-view Sensor (SeaWiFS), it is possible to obtain a synoptic distribution (spatial and temporal) of the phytoplankton biomass (photosynthetic pigments). Even though these data only provide information on the first optical depth, the complement of the biomass in the euphotic zone can be estimated using empirical equations between surface chlorophyll and integrated chlorophyll in the productive 
Valdez-Holguín et al: Productividad primaria a partir de relación irradiancia superficial-clorofila

Lista de símbolos / List of symbols

$\begin{array}{ll}\overline{\mathrm{C}}_{\mathrm{pd}} & \begin{array}{l}\text { Concentración promedio de clorofila en la primera profun concentration of chlorophyll in the first optical dep } \\ \text { Mean con }\end{array} \\ \mathrm{Cla} & \begin{array}{l}\text { Concentración de clorofila } a\left(\mathrm{mg} \mathrm{m}^{-3}\right) \\ \text { Concentration of chlorophyll } a\left(\mathrm{mg} \mathrm{m}^{-3}\right) .\end{array} \\ \mathrm{C} & \begin{array}{l}\text { Concentración de clorofila superficial }\left(\mathrm{mg} \mathrm{m}^{-3}\right) . \\ \text { Concentration of surface chlorophyll }\left(\mathrm{mg} \mathrm{m}^{-3}\right) .\end{array} \\ \mathrm{K}_{\mathrm{d}} & \begin{array}{l}\text { Coeficiente de atenuación vertical de luz difusa }\left(\mathrm{m}^{-1}\right) . \\ \text { Vertical attenuation coefficient of diffused light }\left(\mathrm{m}^{-1}\right) .\end{array}\end{array}$

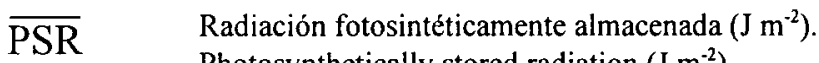

Photosynthetically stored radiation $\left(\mathrm{J} \mathrm{m}^{-2}\right)$.

$\operatorname{PAR}_{\left(0^{+}\right)} \quad$ Radiación fotosintéticamente activa $\left(\mathrm{J} \mathrm{m}^{-2}\right)$.

Photosynthetically active radiation $\left(\mathrm{J} \mathrm{m}^{-2}\right)$.

$\mathrm{E}_{\left(0^{+}\right)} \quad$ Irradiancia incidente sobre la superficie del mar $\left(\mu \mathrm{E} \mathrm{m}^{-2} \mathrm{~s}^{-1}\right)$.

Incident irradiance on the ocean surface $\left(\mu \mathrm{E} \mathrm{m}^{-2} \mathrm{~s}^{-1}\right)$.

$\langle\mathrm{Cl} a\rangle_{\mathrm{tot}} \quad$ Clorofila $a$ integrada en la zona eufótica $\left(\mathrm{g} \mathrm{m}^{-2}\right)$.

Integrated chlorophyll $a$ in the euphotic zone $\left(\mathrm{g} \mathrm{m}^{-2}\right)$.

$\Psi^{*} \quad$ Sección transversal para la fotosíntesis de la columna de agua por unidad de clorofila $\left(\mathrm{m}^{2}[\mathrm{gCl} a]^{-1}\right)$.

Cross-section for photosynthesis per unit of areal chlorophyll in the water column $\left(\mathrm{m}^{2}[\mathrm{gCl} a]^{-1}\right)$.

$\Psi^{*} \quad$ Sección transversal para la fotosíntesis de la columna de agua por unidad de clorofila estimada para primavera en el golfo de California $\left(\mathrm{m}^{2}[\mathrm{gCl} a]^{-1}\right)$.

Cross-section for photosynthesis per unit of areal chlorophyll in the water column, estimated for spring in the Gulf of California $\left(\mathrm{m}^{2}[\mathrm{gCl} a]^{-1}\right)$.

$\Psi^{*}$ Sección transversal para la fotosíntesis de la columna de agua por unidad de clorofila estimada en el golfo de California $\left(\mathrm{m}^{2}\left[\mathrm{gCl}^{-1}\right)\right.$.

Cross-section for photosynthesis per unit of areal chlorophyll in the water column of the Gulf of California $\left(\mathrm{m}^{2}[\mathrm{gCl} a]^{-1}\right)$.

$\mathrm{P}_{\text {tot }} \quad$ Productividad primaria integrada en la zona eufótica $\left(\mathrm{gC} \mathrm{m}^{-2}\right)$.

Integrated primary productivity in the euphotic zone $\left(\mathrm{gC} \mathrm{m}^{-2}\right)$. 
superficial y la clorofila integrada en la zona productiva (Morel y Berthon, 1989). Este tipo de relaciones se han determinado para el golfo de California y se ha propuesto un pérfil normalizado promedio de los pigmentos en la zona eufótica para invierno (Cervantes-Duarte et al., 1993). Falta calcular la productividad primaria de la columna de agua a partir de estas relaciones y de modelos que relacionen la clorofila e irradiancia con la productividad primaria, para obtener mapas regionales de la misma. Sin embargo, para llegar a este valor es necesario conocer los parámetros en que se fundamentan estas estimaciones, con base en los modelos.

Los factores de primer orden que determinan la producción primaria en el océano son la irradiancia incidente y la concentración de pigmentos fotosintéticos (Platt y Sathyendranath, 1993). Desde hace más de 50 años se han desarrollado modelos para estimar la producción primaria diaria de la columna de agua, como una función de la irradiancia y de la biomasa del fitoplancton. Ryther (1956) expresó la productividad de la columna de agua como una función relativa de la fotosíntesis y la irradiancia total diaria en cultivos de laboratorio, considerando fotoinhibición. El método de Talling (1957) está fundamentado también en la respuesta instantánea de la relación fotosintesisirradiancia, sin tomar en cuenta la fotoinhibición; ambos están basados en planimetría para estimar la productividad diaria de la columna de agua. Aparentemente, la producción de la columna de agua normalizada por la biomasa de la zona eufótica es una función lineal de la irradiancia superficial diaria (Platt, 1986). La estimación de esa producción está dada por una función adimensional de la irradiancia (la cual contiene la forma de la curva P-E y la variación sinusoidal de la irradiancia en el día) multiplicada por un factor de escala (Platt et al., 1990). La función adimensional de la irradiancia puede ser tabulada para el intervalo ecológico de interés (Platt y Sathyendranath, 1993). Sin embargo, todos los modelos anteriores suponen que la biomasa fitoplanctónica y los parámetros fotosinteticos son homogéneos con la profundidad; además, consideran una variación sinusoidal de la irradiancia superficial y que no existen zone (Morel and Berthon, 1989). These types of equations have been determined for the Gulf of California and a mean normalized profile has been proposed for the pigments in the euphotic zone during winter (Cervantes-Duarte et al., 1993). Primary productivity in the water column remains to be calculated using these equations and models that relate chlorophyll and irradiance with primary productivity, in order to obtain regional maps. However, in order to reach this value, it is necessary to know the parameters on which these estimations are founded, based on the models.

The first-order factors that determine primary production in the ocean are incident irradiance and the concentration of photosynthetic pigments (Platt and Sathyendranath, 1993). From more than 50 years ago, models have been developed to estimate daily primary production in the water column, as a function of irradiance and of phytoplankton biomass. Ryther (1956) expressed productivity in the water column as a relative function of photosynthesis and total daily irradiance in laboratory cultures, taking into account photoinhibition. Talling's method (1957) is also founded on the instantaneous response between photosynthesis-irradiance, but it does not consider photoinhibition; both are based on planimetry for estimating daily productivity in the water column. Apparently, production in the water column, normalized by the biomass in the euphotic zone, is a linear function of daily surface irradiance (Platt, 1986). The estimate of this production is given as an adimensional function of irradiance (which contains the form of the P-E curve and sinusoidal variation in irradiance during the day) multiplied by a scale factor (Platt et al., 1990). The adimensional function of irradiance can be tabulated for the ecological interval of choice (Platt and Sathyendranath, 1993). However, all of the previous models assume that the phytoplankton biomass and photosynthetic parameters are homogenous at any depth. They also consider a sinusoidal variation in the surface irradiance, and that the quality of light does not change with depth. The effect of the spectral quality of irradiance on photosynthesis has been theoretically discussed (Morel, 1978) 
efectos de la calidad de la luz con la profundidad. El efecto de la calidad espectral de la irradiancia en la fotosíntesis ha sido discutido teóricamente (Morel, 1978), asi como en la pendiente inicial $(\alpha)$ de la relación P-E (Lewis et $a l ., 1985)$ y en la eficiencia cuántica $\left(\phi_{\max }\right)$ (Cleveland et al., 1989). Considerar estas correcciones espectrales o no, en los modelos, puede conducir a estimaciones erróneas de la productividad hasta de un $60 \%$, en comparación con datos in situ (Kyelwalyanga et al., 1992).

La energía solar fotosintéticamente almacenada en la zona eufótica ( $\overline{\mathrm{PSR}}$ ), en primera instancia es proporcional a la radiación fotosintéticamente disponible en la supcrficie $E_{\left(0^{+}\right)}$y a la biomasa fitoplanctónica integrada en la zona eufótica $\langle\mathrm{Cl} a\rangle_{\text {tot }}$ (Morel y Berthon, 1989). Esta relación se establece a través del parámetro $\Psi^{*}$, que es la sección transversal para fotosíntesis por unidad de clorofila para toda la columna de agua, con dimensiones $\mathrm{m}^{2}(\mathrm{gCl} a)^{-1}$. Morel (1978) reportó un valor promedio de $\Psi^{*}=$ $0.07 \pm 0.035 \mathrm{~m}^{2}(\mathrm{gCl} a)^{-1}$ para una gran diversidad de situaciones tróficas, desde aguas oligotróficas hasta aguas eutróficas. Sin embargo, este parámetro fisiológico está pobremente documentado y su valor puede variar en función de la estación del año, área de estudio y características ambientales (Morel, 1991). El uso de estos parámetros para estimar la productividad de la columna de agua a escala regional aporta mayor informacion del flujo de carbono que las estimaciones puntuales de productividad.

En este trabajo se propone un valor promedio del parámetro $\Psi^{*}$ para el golfo de California durante la primavera, el cual puede ser utilizado para calcular la productividad primaria de la región, con datos de irradiancia superficial y clorofila $a$. Los valores de productividad primaria calculados con este parámetro (utilizando el valor promedio para primavera y el propuesto por Morel, 1978) son comparados con resultados obtenidos a partir de incubaciones $\operatorname{con}^{14} \mathrm{C} y$ estimaciones hechas a partir de la fluorescencia natural, realizadas durante mayo de 1992 . Nuestra hipótesis es que el valor de $\Psi^{*}$ propuesto por Morel (1978) no es directamente aplicable a las estimaciones de la productividad en todo el golfo ni durante cualquier estación del año. as well as the initial slope $(\alpha)$ of the P-E equation (Lewis et al., 1985) and of the quantum efficiency $\left(\phi_{\max }\right)$ (Cleveland et al., 1989). To consider these spectral corrections or not in the models can lead to erroneous estimates of productivity of up to $60 \%$, compared to in situ data (Kyelwalyanga et al, 1992).

The photosynthetically stored solar radiation in the euphotic zone ( $\overline{\mathrm{PSR}})$, in first instance is proportional to the radiation photosynthetically available in the surface $E_{\left(0^{+}\right)}$and to the integrated phytoplankton biomass in the euphotic zone $<\mathrm{Cl} a\rangle_{\text {tot }}$ (Morel and Berthon, 1989). This equation is established through the $\Psi^{*}$ parameter, which is the cross-scction for photosynthesis per unit of areal chlorophyll, with dimensions $\mathrm{m}^{2}\left(\mathrm{gCla}^{-1}\right.$. Morel (1978) reported a mean value of $\Psi^{*}=0.07 \pm 0.035 \mathrm{~m}^{2}$ $(\mathrm{gCl} a)^{-1}$ for a wide variety of trophic situations, from oligotrophic to eutrophic waters. However, this physiological parameter is poorly documented and its value can vary in function with the yearly season, study area and environmental characteristics (Morel, 1991). The use of these parameters for estimating productivity in the water column at a regional scale provides greater information on the carbon flow than punctual estimates of productivity.

In this study, a mean value of the $\Psi^{*}$ parameter is proposed for the Gulf of California during the spring, which can be used to calculate primary productivity of the region using surface irradiance and chlorophyll $a$ data. The values of primary productivity calculated with this parameter (using the mean value for spring and that proposed by Morel, 1978) are compared to results obtained from incubations with ${ }^{14} \mathrm{C}$ and estimates with natural fluorescence during May 1992. Our hypothesis is that the $\Psi^{*}$ value proposed by Morel (1978) is not directly applicable to estimates of productivity in the entire gulf, nor to any season of the year.

\section{MATERIALS AND METHODS}

Measurements of chlorophyll, irradiance and primary productivity were taken from 20 stations in the Gulf of California from 22 to 27 May 1992, aboard the ship BIP XI (fig. 1). The 


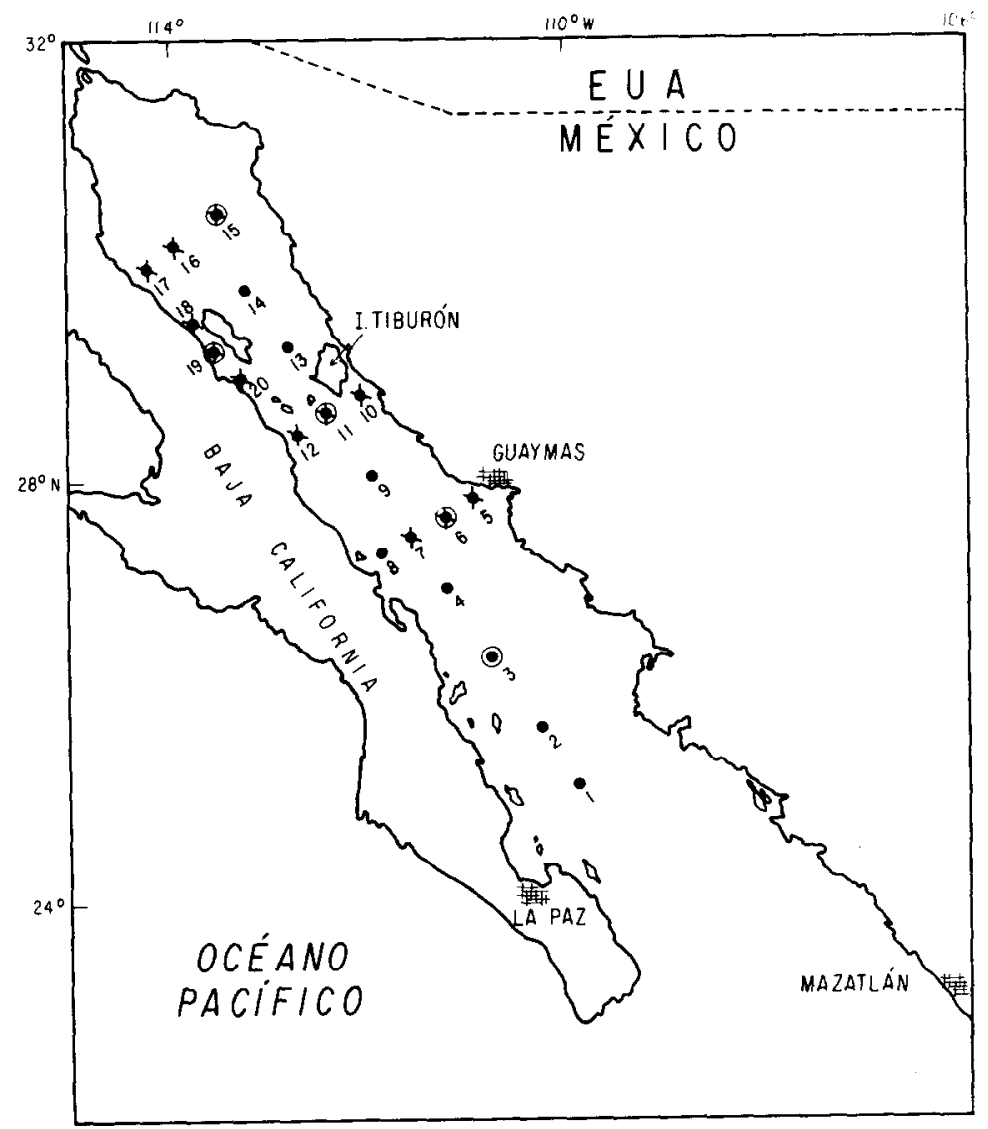

Figura 1. Localización de las estaciones de muestreo. En las estaciones marcadas $\odot$, se llevaron a cabo experimentos de productividad primaria in situ por el método del ${ }^{14} \mathrm{C}$. En las estaciones marcadas $\times$, se hicieron mediciones con el perfilador de fluorescencia natural (PNF-300).

Figure 1. Locations of the sample sites. In the stations marked $\odot$, in situ experiments were conducted on primary productivity using the ${ }^{14} \mathrm{C}$ method. In the stations marked $\times$, measurements were taken with the natural fluorescence profiler (PNF-300).

\section{MATERIALES Y MÉTODOS}

Las mediciones de clorofila, irradiancia y productividad primaria fueron realizadas a lo largo de 20 estaciones en el golfo de California del 22 al 27 de mayo de 1992, a bordo del BIP $X I$ (fig. 1). Los códigos de las estaciones están referidos a la distancia (millas naúticas) del punto de muestreo con la cabeza del golfo y la costa de la península de Baja California.

Las muestras para el análisis de clorofila fueron tomadas con botellas Niskin a profundi- station codes are referenced to the distance (nautical miles) from the sample site to the head of the gulf and to the coast of the Baja California Peninsula.

Samples for chlorophyll analysis were taken with Niskin bottles at standard depths of 0 , $10,20,30,50,75$ and $100 \mathrm{~m}$, or to the depth allowed by the sea floor. The samples were passed through GF/C filters with a diameter of $47 \mathrm{~mm}$, and frozen until their analysis in the laboratory. The photosynthetic pigments were extracted with $10 \mathrm{ml}$ of $90 \%$ acetone in $20 \mathrm{ml}$ 
dades estándar de $0,10,20,30,50,75$ y $100 \mathrm{~m}$, o hasta donde la profundidad del fondo lo permitía. Las muestras se pasaron a través de filtros $\mathrm{GF} / \mathrm{C}$ de $47 \mathrm{~mm}$ de diámetro, y éstos fueron congelados hasta su análisis en el laboratorio. Los pigmentos fotosintéticos fueron extraidos con $10 \mathrm{ml}$ de acetona al $90 \%$, en frascos de vidrio de $20 \mathrm{ml}$, por $24 \mathrm{~h}$ en un lugar frío y obscuro (Venrick y Hayward, 1984). La densidad óptica de las muestras se determinó con un espectrofotómetro Beckman modelo 25, siguiendo la técnica de Parsons et al. (1984). La concentración de pigmentos se calculó con las ccuaciones de Parsons y Strickland (1963).

El perfil de radiación fotosintéticamente activa (PAR) fue medido con un sensor de irradiancia escalar acoplado a un perfilador de fluorescencia natural (PNF-300; Biospherical Instruments Inc.), el cual también tiene un sensor para la PAR superficial $\left(\mathrm{E}_{\left(0^{+}\right)}\right)$.

La productividad primaria del fitoplancton fue determinada con la técnica del ${ }^{14} \mathrm{C}$ de Stecmann Nielsen (1952). Las muestras fueron recolectadas con botellas Niskin a profundidades que correspondian al $93,54,25,15$ y $7 \%$ de $\mathrm{E}_{\mathrm{j}}$, e incubadas bajo condiciones in situ $\mathrm{y}$ simuladas a bordo del barco. Las incubaciones simuladas a bordo se realizaron en tubos transparentes de acrílico, forrados de malla ópticamente neutra para simular la irradiancia in situ de la muestra. La temperatura dentro de los tubos se controló circulando agua de mar superficial a través de ellos. Las muestras fueron inoculadas con $3.177 \mu \mathrm{Ci}$ de ${ }^{14} \mathrm{C}$ en botellas de policarbonato de $250 \mathrm{ml}$ de capacidad e incubadas alrededor del mediodía por dos horas. Posteriormente, se pasaron por filtros de membrana de $0.45 \mu \mathrm{m}$ de poro y se colocaron en frascos para centelleo líquido con $10 \mathrm{ml}$ de Aquasol. La actividad del ${ }^{14} \mathrm{C}$ fue determinada con un contador de centelleo líquido Beckman LS-5000, en la Universidad Autónoma de Baja California. Los valores fueron extrapolados hasta el $1 \%$ de $E_{i i}$ (fondo de la zona eufótica), suponiendo que la productividad primaria tiende a cero en esta profundidad.

A partir de las mediciones de fluorescencia natural del fitoplancton, se obtuvieron estimaciones de la productividad primaria. Se supone glass jars for $24 \mathrm{~h}$ in a cool, dark place (Venrick and Hayward, 1984). Optical density of the samples was determined with a Beckman spectrophotometer model 25 , following the technique of Parsons et al. (1984). The concentration of pigments was calculated using the equations of Parsons and Strickland (1963).

The profile of photosynthetically active radiation (PAR) was measured with a scalar irradiance sensor, coupled to a natural fluorescence profiler (PNF-300; Biospherical Instruments Inc.), which also has a sensor for surface $\operatorname{PAR}\left(\mathrm{E}_{\left(0^{+}\right)}\right)$.

Phytoplankton productivity was determined using the ${ }^{14} \mathrm{C}$ technique of Steemann Nielsen (1952). The samples were collected with Niskin bottles at depths corresponding to $93,54,25$, 15 and $7 \%$ of $E_{0}$, and incubated under in situ and simulated conditions aboard the ship. The incubations simulated aboard the ship were conducted in transparent acrylic tubes, covered with optically neutral mesh in order to simulate the in situ irradiance of the sample. The temperature within the tubes was controlled by circulating superficial seawater through them. The samples were inoculated with $3.177 \mu \mathrm{Ci}$ of ${ }^{14} \mathrm{C}$ in $250 \mathrm{ml}$ polycarbonate bottles and incubated around noon for two hours. Later, they were passed through $0.45 \mu \mathrm{m}$ pore membrane filters and were placed in liquid scintillation vials with $10 \mathrm{ml}$ of Aquasol. ${ }^{14} \mathrm{C}$ activity was determined with a Beckman LS-5000 liquid scintillation counter at the Universidad Autónoma de Baja California. The values were extrapolated up to $1 \%$ of $E_{0}$ (bottom of the euphotic zone), assuming that primary productivity leans towards zero at this depth.

Estimates of primary productivity were obtained from the natural fluorescence measurements of the phytoplankton. It is assumed that all of the natural fluorescence (radiance centered at $683 \mathrm{~nm}$ ) measured with the profiler is due to chlorophyll $a$. In order to estimate productivity with this method, the ratio of natural fluorescence is related to the photosynthetic ratio using an empirical equation (Chamberlin et al., 1990). In this model, the natural fluorescence of the phytoplankton and irradiance (PAR) are the variables, where the ratio 
que toda la fluorescencia natural (radiancia centrada a $683 \mathrm{~nm}$ ) medida con el perfilador es debida a la clorofila $a$. Para estimar la productividad por este método, la tasa de fluorescencia natural se relaciona con la tasa fotosintética mediante una ecuación empírica (Chamberlin et al., 1990). En este modelo la fluorescencia natural del fitoplancton y la irradiancia (PAR) son las variables, donde se supone constante la razón entre las eficiencias cuánticas de fotosíntesis y fluorescencia (2.3 átomos de carbono asimilado por fotón emitido) y el valor de la irradiancia de $133 \mu \mathrm{E} \mathrm{m}^{-2} \mathrm{~s}^{-1}$, cuando esta razón es la mitad de su máximo.

Además, la fijación diaria de carbono $\left(\mathrm{P}_{\mathrm{tot}}\right)$ se estimó utilizando el modelo espectral de Morel y Berthon (1989):

$$
\begin{gathered}
\overline{\mathrm{PSR}}=\mathrm{PAR}_{\left(0^{+}\right)}<\mathrm{Cl} a>_{\mathrm{tot}} \Psi^{*} \\
\mathrm{P}_{\mathrm{tot}}=\overline{\mathrm{PSR}} / 39
\end{gathered}
$$

En este modelo se supone un factor de conversión constante entre $\overline{\mathrm{PSR}}$ y productividad, igual a 39 K.J por cada gramo de carbono asimilado (Platt, 1986). Se utilizó un valor promedio de $\mathrm{PAR}_{\left(0^{+}\right)}$para toda la región, con base en los datos de $\mathrm{E}_{\mathrm{n}}$ del perfilador y la duración del día solar, de acuerdo con la latitud y fecha (Kirk, 1983). La duración calculada del día solar fue de $13.5 \mathrm{~h}$, con una $\operatorname{PAR}_{\left(0^{+}\right)}$diaria total de $\left.22,414 \mathrm{KJ} \mathrm{m}^{-2} . \mathrm{La}<\mathrm{Cl} a\right\rangle_{\text {tot }}$ se calculó según el modelo de Morel y Berthon (i989), en forma similar al del reportado por Cervantes-Duarte $e t$ al. (1993). El contenido de clorofila en la zona eufótica durante el día se considera constante. Con datos de productividad primaria y clorofila del golfo de California (Gaxiola-Castro y Álvarez-Borrego, 1986; Valdez-Holguín y Lara-Lara, 1987; Álvarez-Borrego y GaxiolaCastro, 1988; Lara-Lara y Valdez-Holguín, 1988) se estimó, partiendo de las ecuaciones 1 y 2, un valor promedio del parámetro $\Psi^{*}\left(\Psi^{*}{ }_{\text {iot }}\right.$ para todos los datos y $\Psi_{p}^{*}$ para las primaveras).

$$
\Psi^{*}=\left(39 \mathrm{P}_{\text {tot }}\right) /\left(\mathrm{PAR}_{\left(0^{+}\right)}<\mathrm{Cl} a>_{\text {tot }}\right)
$$

between the quantum efficiencies of photosynthesis and fluorescence ( 2.3 assimilated carbon atoms per photon emitted) is assumed to be constant as well as the irradiance value of $133 \mu \mathrm{E} \mathrm{m}^{-2} \mathrm{~s}^{-1}$, when this ratio is half its maximum.

Furthermore, the daily assimilation of carbon $\left(\mathrm{P}_{\text {tot }}\right)$ was estimated using the spectral method of Morel and Berthon (1989):

$$
\begin{gathered}
\overline{\mathrm{PSR}}=\mathrm{PAR}_{\left(0^{+}\right)}<\mathrm{Cl} a>_{\text {tot }} \Psi^{*} \\
\mathrm{P}_{\text {tot }}=\overline{\mathrm{PSR}} / 39
\end{gathered}
$$

In this model, a constant conversion factor between $\overline{\text { PSR }}$ and productivity is assumed, equal to $39 \mathrm{KJ}$ per gram of assimilated carbon (Platt, 1986). A mean value of $\mathrm{PAR}_{\left(0^{+}\right)}$was used for the entire region, based on the $E_{0}$ data from the profiler and the duration of the solar day, according to latitude and date (Kirk, 1983). The calculated duration of the solar day was $13.5 \mathrm{~h}$, with a total daily $\mathrm{PAR}_{\left(0^{+}\right)}$ equal to $22,414 \mathrm{KJ} \mathrm{m}^{-2}$. The $\langle\mathrm{Cl} a\rangle_{\text {tot }}$ was calculated according to the model of Morel and Berthon (1989), similarly to that reported by Cervantes-Duarte et al. (1993). The chlorophyll content in the euphotic zone during the day is considered to be constant. Using data on primary productivity and chlorophyll from the Gulf of California (Gaxiola-Castro and ÁlvarezBorrego, 1986; Valdez-Holguín and Lara-Lara, 1987; Álvarez-Borrego and Gaxiola-Castro, 1988; Lara-Lara and Valdez-Holguín, 1988) a mean value of the $\Psi^{*}$ parameter was calculated using equations 1 and $2\left(\Psi^{*}{ }_{\text {tot }}\right.$ for all of the data and $\Psi_{p}^{*}$ for the spring seasons).

$$
\Psi^{*}=\left(39 \mathrm{P}_{\mathrm{tot}}\right) /\left(\mathrm{PAR}_{\left(0^{+}\right)}<\mathrm{Cl} a>_{\mathrm{tot}}\right)
$$

The value obtained is considered to be constant for the entire Gulf of California, which is a gross approximation. The productivity estimates using these values $\left(\Psi^{*}\right.$ tot and $\left.\Psi^{*}\right)$ and that proposed by Morel $(1978)\left(\Psi^{*}=0.07\right)$ are compared to data obtained from in situ measurements made with the ${ }^{14} \mathrm{C}$ method. 

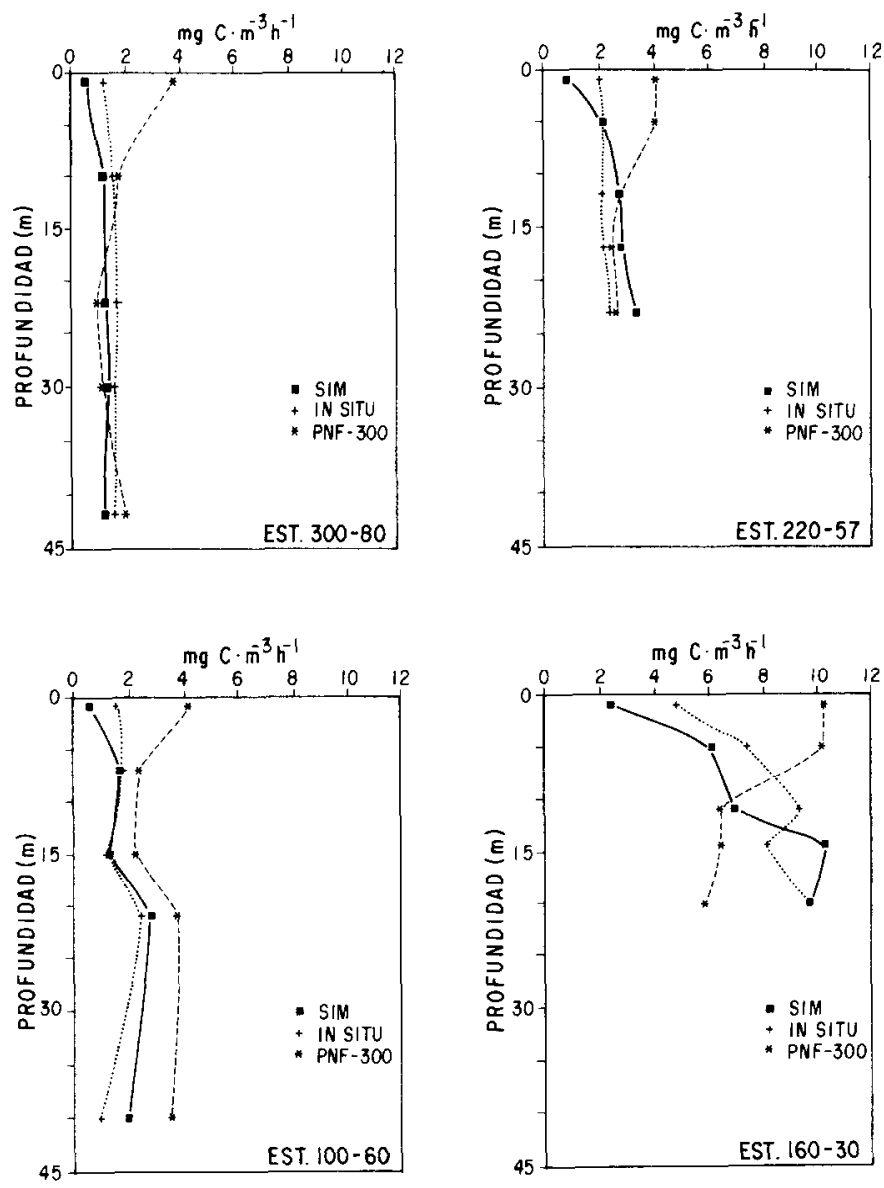

Figura 2. Distribución vertical de la productividad primaria medida con el método del ${ }^{14} \mathrm{C}$, simulada a bordo (SIM) e in situ (IN SITU), y estimada con la fluorescencia natural (PNF-300).

Figure 2. Vertical distribution of primary productivity measured with the ${ }^{14} \mathrm{C}$ method, simulated on board (SIM) and in situ (IN SITU), and estimated using natural fluorescence (PNF-300).

El valor obtenido se considera constante para todo el golfo de California, lo cual es una aproximación muy gruesa. Las estimaciones de la productividad con estos valores $\left(\Psi^{*}\right.$ tol $\left.y \Psi_{p}^{*}\right)$ y el propuesto por Morel $(1978)\left(\Psi^{*}=0.07\right)$ son comparados con datos obtenidos de mediciones in situ hechas con el método del ${ }^{14} \mathrm{C}$.

\section{RESULTADOS}

Los valores de productividad primaria estimados con el método del ${ }^{14} \mathrm{C}$ y con la fluores-

\section{RESULTS}

The primary productivity values estimated with the ${ }^{14} \mathrm{C}$ method and with natural fluorescence of the phytoplankton were very similar in all of the cases (fig. 2). No significant differences $(95 \%)$ were found between the values of productivity determined from the three methods in stations $300-80$ and $160-30$. There were, however, significant differences in stations 220-57 and 100-60. A common characteristic in all of the profiles were the persistently high 
cencia natural del fitoplancton fueron muy similares en todos los casos (fig. 2). En las estaciones $300-80$ y $160-30$ no se encontraron diferencias significativas $(95 \%)$ entre los valores de productividad determinados por los tres métodos. Sin embargo, en las estaciones 220-57 y 100-60 sí fueron significativas las diferencias. Una caracteristica común en todos los perfiles, fue la persistencia de valores altos de productividad en superficie, calculados a partir de la fluorescencia natural, lo cual puede estar asociado a la alta proporción de luz solar de $683 \mathrm{~nm}$ que se encuentra en las primeras capas y que satura el sensor de radiancia $\left(\mathrm{L}_{\mathrm{u} 683}\right)$. El coeficiente de correlación entre los resultados de productividad primaria obtenidos con los métodos de ${ }^{14} \mathrm{C}$ in situ y de fluorescencia natural fue alto $(r=0.70, n=40)$, lo que demuestra que las estimaciones de productividad a partir de fluorescencia natural son consistentes con los valores obtenidos por el método del ${ }^{14} \mathrm{C}$.

Las comparaciones de la productividad integrada para la zona eufótica (tabla 1) muestran que los valores obtenidos a partir de la fluorescencia natural respecto a las estimaciones con el método del ${ }^{14} \mathrm{C}$ difieren hasta por un $30 \%$, y que en algunas ocasiones puede llegar hasta un $90 \%$ (estación 160-30). Los altos valores de productividad integrada calculados a partir de la fluorescencia natural para los muestreos realizados temprano en la mañana o al atardecer (estaciones 300-100, 300-65, 220-80, $220-40,100-40,100-20,140-25$ y 180-30) hacen suponer que en estas estaciones existe una desviación de la estimación de la productividad asociada con la irradiancia in situ y la extrapolación de la productividad para todo el día.

Los perfiles de clorofila (fig. 3) fueron caracterizados en el área de estudio con un máximo subsuperficial (entre 10 y $50 \mathrm{~m}$ de profundidad), con una concentración promedio de clorofila superficial de $0.71 \mathrm{mg} \mathrm{m}^{-3} \mathrm{y}$ una desviación estándar de 0.33 . El perfil promedio de biomasa del golfo de California para esta estación del año muestra un máximo aproximadamente en el $10 \%$ de $E_{0}(30 \mathrm{~m})$ (fig. 4). La profundidad de la zona eufótica y la biomasa integrada, calculados a partir de los perfiles de cada estación y el modelo de Morel y Berthon productivity values in the surface, which were calculated from the natural fluorescence, and can be associated to the high proportion of solar light, $683 \mathrm{~nm}$, that is found in the first layers and saturates the radiance sensor $\left(\mathrm{L}_{\mathrm{u} 683}\right)$. The correlation coefficient between the results of primary productivity obtained with the in situ ${ }^{14} \mathrm{C}$ and natural fluorescence methods was high $(r=0.70, n=40)$, which demonstrates that the estimates of productivity using natural fluorescence are consistent with the values obtained from the ${ }^{14} \mathrm{C}$ method.

The comparisons of integrated productivity in the euphotic zone (table 1) show that the values obtained from natural fluorescence with respect to the estimates with the ${ }^{14} \mathrm{C}$ method differ by up to $30 \%$ and that, on some occasions, can reach up to $90 \%$ (station 160-30). One can assume from the high values of integrated productivity calculated from natural fluorescence in the samplings conducted early in the morning or at dusk (stations 300-100, 300-65, $220-80,220-40,100-40,100-20,140-25$ and 180-30), that a deviation exists in the productivity estimate associated with the in situ irradiance and the extrapolation of productivity for the entire day.

The chlorophyll profiles in the study area (fig. 3) were characterized by a subsurface maximum (between 10 and $50 \mathrm{~m}$ deep), with a mean concentration of surface chlorophyll of $0.71 \mathrm{mg} \mathrm{m}^{-3}$ and a standard deviation of 0.33 . The mean biomass profile for the Gulf of California in this season of the year shows a maximum at approximately $10 \%$ of $E_{0}(30 \mathrm{~m})$ (fig. 4). The depth of the euphotic zone and the integrated biomass calculated from the profiles of each station and from the model of Morel and Berthon (1989), considering a euphotic zone shallower than $102 \mathrm{~m}$, are shown in table 1. The mean depth estimated for the euphotic zone of the Gulf of California was $39 \mathrm{~m}$ and $36.96 \mathrm{mg} \mathrm{m}^{-2}$ for the integrated biomass, with a standard deviation of 6.38 and 9.17 , respectively.

The values (mean \pm one standard deviation) of the parameters were $\Psi^{*}{ }_{\text {tot }}=0.048 \pm 0.035 \mathrm{~m}^{2}$ $(\mathrm{gCl} a)^{-1}$ and $\Psi_{\mathrm{p}}^{*}=0.039 \pm 0.017 \mathrm{~m}^{2}(\mathrm{gCl} a)^{-1}$, which are lower than that proposed by Morel 
Valdez-Holguin et al.: Productividad primaria a partir de relación irradiancia superficial-clorofila

Tabla 1. Comparación de la productividad integrada en la zona eufótica del golfo de California, medida con el método de ${ }^{14} \mathrm{C}$ (in situ) y estimada con fluorescencia natural (PNF-300) y utilizando el modelo de Morel y Berthon (1989). Las unidades están dadas en $\mathrm{gC}^{-2} \mathrm{~d}^{-1}$. Las estimaciones fueron obtenidas con los valores de: $\Psi^{*}=0.07 \pm 0.035 \mathrm{~m}^{2}(\mathrm{gCl} a)^{-1}, \Psi_{\mathrm{p}}^{*}=0.039 \pm 0.017 \mathrm{~m}^{2}(\mathrm{gCl} a)^{-1} \mathrm{y}$ $\Psi_{\text {tol }}=0.048 \pm 0.035 \mathrm{~m}^{2}(\mathrm{gCl} a)^{-1}$. La profundidad de la zona eufótica (Ze, en metros) y la clorofila integrada en la zona eufótica (Cla Ze, en $\mathrm{mg} \mathrm{m}^{-2}$ ) se estimaron con el modelo de Morel y Berthon (1989).

Table 1. Comparison of integrated productivity in the euphotic zone of the Gulf of California measured with the ${ }^{14} \mathrm{C}$ method (in situ), estimated from natural fluorescence (PNF-300) and using the method of Morel and Berthon (1989). The units are given in $\mathrm{gC} \mathrm{m}^{-2} \mathrm{~d}^{-1}$. The estimates were obtained with the values: $\Psi^{*}=0.07 \pm 0.035 \mathrm{~m}^{2}(\mathrm{gCla})^{-1}, \Psi^{*}{ }_{\mathrm{p}}=0.039 \pm 0.017 \mathrm{~m}^{2}(\mathrm{gCl} a)^{-1}$ and $\Psi_{\text {tol }}=0.048 \pm$ $0.035 \mathrm{~m}^{2}(\mathrm{gCl} a)^{-1}$. The depth (Ze, in meters) and integrated chlorophyll (Cla $\mathrm{Ze}$, in $\mathrm{mg} \mathrm{m}^{-2}$ ) of the euphotic zone were estimated using the model of Morel and Berthon (1989).

\begin{tabular}{|c|c|c|c|c|c|c|c|c|c|}
\hline $\begin{array}{l}\text { No. de } \\
\text { estación }\end{array}$ & $\begin{array}{l}\text { Código } \\
\text { estación }\end{array}$ & $\begin{array}{l}\text { Hora de } \\
\text { muestreo }\end{array}$ & $\begin{array}{c}\mathrm{Ze} \\
\mathbf{m}\end{array}$ & $\begin{array}{l}\mathrm{Cla} \mathrm{Ze} \\
\mathrm{mg} \mathrm{m}^{-2}\end{array}$ & 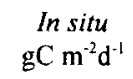 & 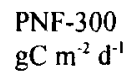 & $\begin{array}{c}\Psi^{*} \\
\mathrm{gC} \mathrm{m}^{-2} \mathrm{~d}^{-1}\end{array}$ & $\begin{array}{c}\Psi^{*} \\
\mathrm{gC} \mathrm{m}^{-2} \mathrm{~d}^{-1}\end{array}$ & $\begin{array}{c}\Psi^{*} \\
\mathrm{gC} \mathrm{m}^{-2} \mathrm{~d}^{-1}\end{array}$ \\
\hline 1 & $460-73$ & $16: 00$ & 36 & 40.33 & & & 1.22 & 0.68 & 0.83 \\
\hline 2 & $420-70$ & $22: 17$ & 51 & 25.17 & & & 0.76 & 0.43 & 0.52 \\
\hline 3 & $380-87$ & $05: 35$ & 44 & 30.50 & & & 0.92 & 0.52 & 0.63 \\
\hline 4 & 340.65 & $12: 05$ & 54 & 23.67 & 0.50 & & 0.71 & 0.40 & 0.49 \\
\hline 5 & $300-100$ & $06: 15$ & 40 & 35.08 & & 2.82 & 1.06 & 0.59 & 0.73 \\
\hline 6 & $300-80$ & $11: 47$ & 39 & 36.39 & 0.47 & 0.35 & 1.10 & 0.62 & 0.75 \\
\hline 7 & $300-65$ & $17: 20$ & 43 & 32.02 & & 4.92 & 0.97 & 0.54 & 0.66 \\
\hline 8 & $300-40$ & 21:06 & 41 & 33.61 & & & 1.01 & 0.57 & 0.70 \\
\hline 9 & $260-60$ & 03:14 & 45 & 30.11 & & & 0.91 & 0.51 & 0.62 \\
\hline 10 & $220-80$ & $08: 40$ & 32 & 48.24 & & 0.88 & 1.46 & 0.82 & 1.00 \\
\hline 11 & $220-57$ & $11: 52$ & 36 & 40.01 & 0.59 & 0.52 & 1.21 & 0.68 & 0.83 \\
\hline 12 & $220-40$ & $17: 02$ & 32 & 48.93 & & 4.05 & 1.48 & 0.83 & 1.01 \\
\hline 13 & $180-55$ & $22: 28$ & 26 & 62.76 & & & 1.89 & 1.06 & 1.30 \\
\hline 14 & $140-55$ & $03: 30$ & 40 & 26.11 & & & 0.79 & 0.44 & 0.54 \\
\hline 15 & $100-60$ & $09: 45$ & 40 & 34.99 & 0.54 & 0.82 & 1.06 & 0.59 & 0.72 \\
\hline 16 & $100-40$ & $15: 30$ & 37 & 39.59 & & 3.55 & 1.19 & 0.67 & 0.82 \\
\hline 17 & $100-20$ & $18: 45$ & 34 & 44.09 & & 3.85 & 1.33 & 0.75 & 0.91 \\
\hline 18 & $140-25$ & $07: 20$ & 41 & 34.30 & & 4.69 & 1.03 & 0.58 & 0.71 \\
\hline 19 & $160-30$ & $10: 49$ & 37 & 39.05 & 1.89 & 0.99 & 1.18 & 0.66 & 0.81 \\
\hline 20 & $180-30$ & $15: 30$ & 41 & 34.33 & & 2.31 & 1.04 & 0.58 & $0.7 I$ \\
\hline & Promedio & & 39.45 & 36.96 & 0.8 & 2.48 & 1.11 & 0.63 & 0.76 \\
\hline
\end{tabular}



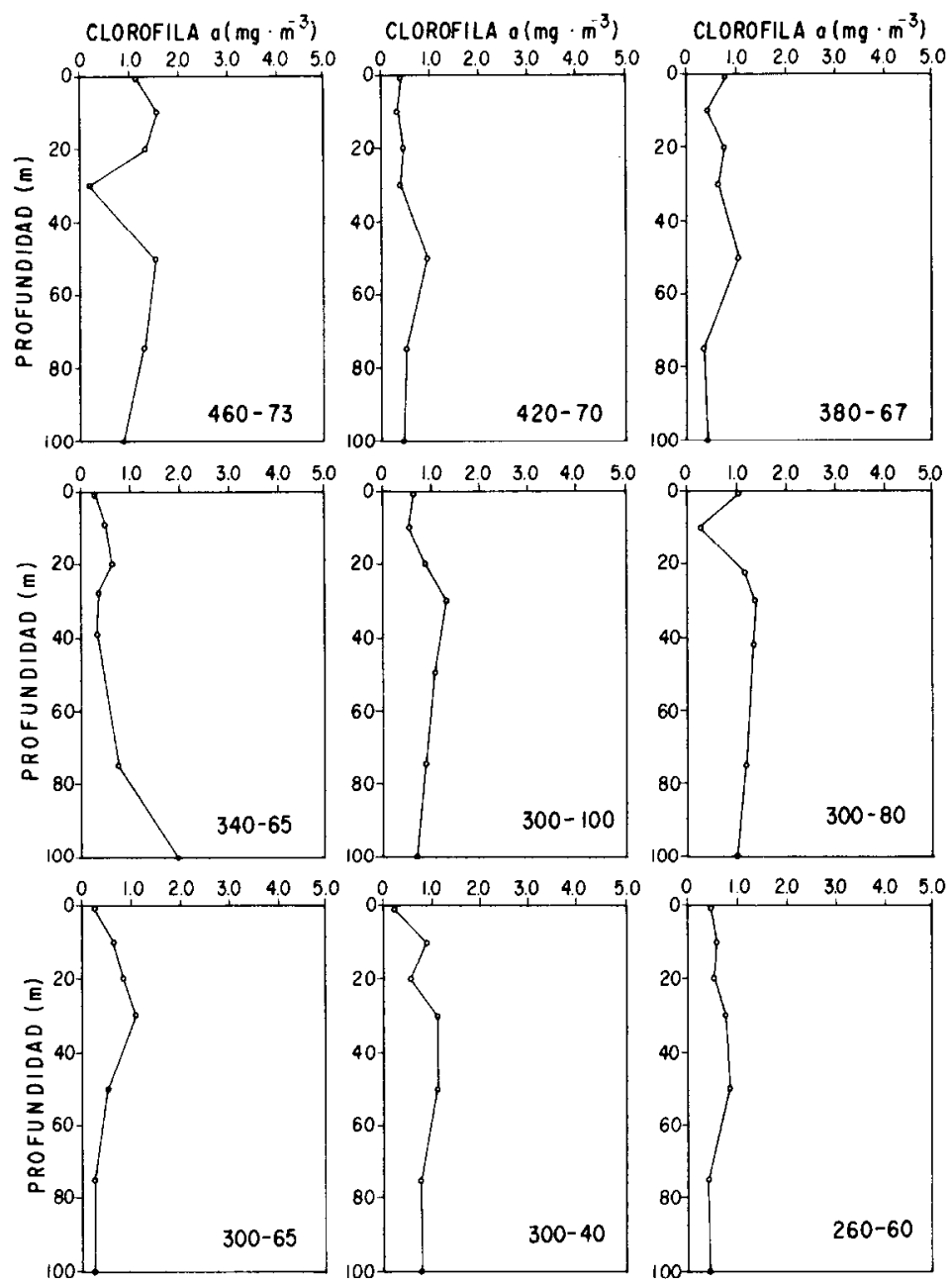

Figura 3. Perfiles verticales de la clorofila $\left(\mathrm{mg} \mathrm{m}^{-3}\right)$.

Figure 3. Vertical profiles of the chlorophyll $\left(\mathrm{mg} \mathrm{m}^{-3}\right)$.

(1989), considerando una zona eufótica menor de $102 \mathrm{~m}$, se presentan en la tabla 1 . La profundidad promedio estimada de la zona eufótica del golfo de California fue de $39 \mathrm{~m}$ y la biomasa integrada $36.96 \mathrm{mg} \mathrm{m}^{-2}$, con una desviación estándar de 6.38 y 9.17 , respectivamente.

Los valores (promedio \pm una desviación estándar) de los parámetros fueron $" \Psi^{*}{ }_{101}=$ $0.048 \pm 0.035 \mathrm{~m}^{2}(\mathrm{gCl} a)^{-1}$ y $\Psi_{\mathrm{p}}^{*}=0.039 \pm$ $0.017 \mathrm{~m}^{2}(\mathrm{gCl} a)^{-1}$, los cuales son menores que el propuesto por Morel $\left(1978 ; \Psi^{*}=0.07 \pm\right.$ $\left(1978 ; \Psi^{*}=0.07 \pm 0.035 \mathrm{~m}^{2}[\mathrm{gCl} a]^{-1}\right)$. Howev$\mathrm{er}$, the estimated values of primary productivity during the spring in the gulf using the value proposed by Morel (1978) overestimates the value obtained with the ${ }^{14} \mathrm{C}$ method by up to $100 \%$ (stations 340-65, 300-80, 220-57 and 100-60) (table 1). The integrated productivity value estimated for station $160-30$ underestimates the one measured with ${ }^{14} \mathrm{C}$ by $60 \%$. Estimated productivity using values of this parameter calculated from historical data from the 
Valdez-Holguín et al.: Productividad primaria a partir de relación irradiancia superficial-clorofila
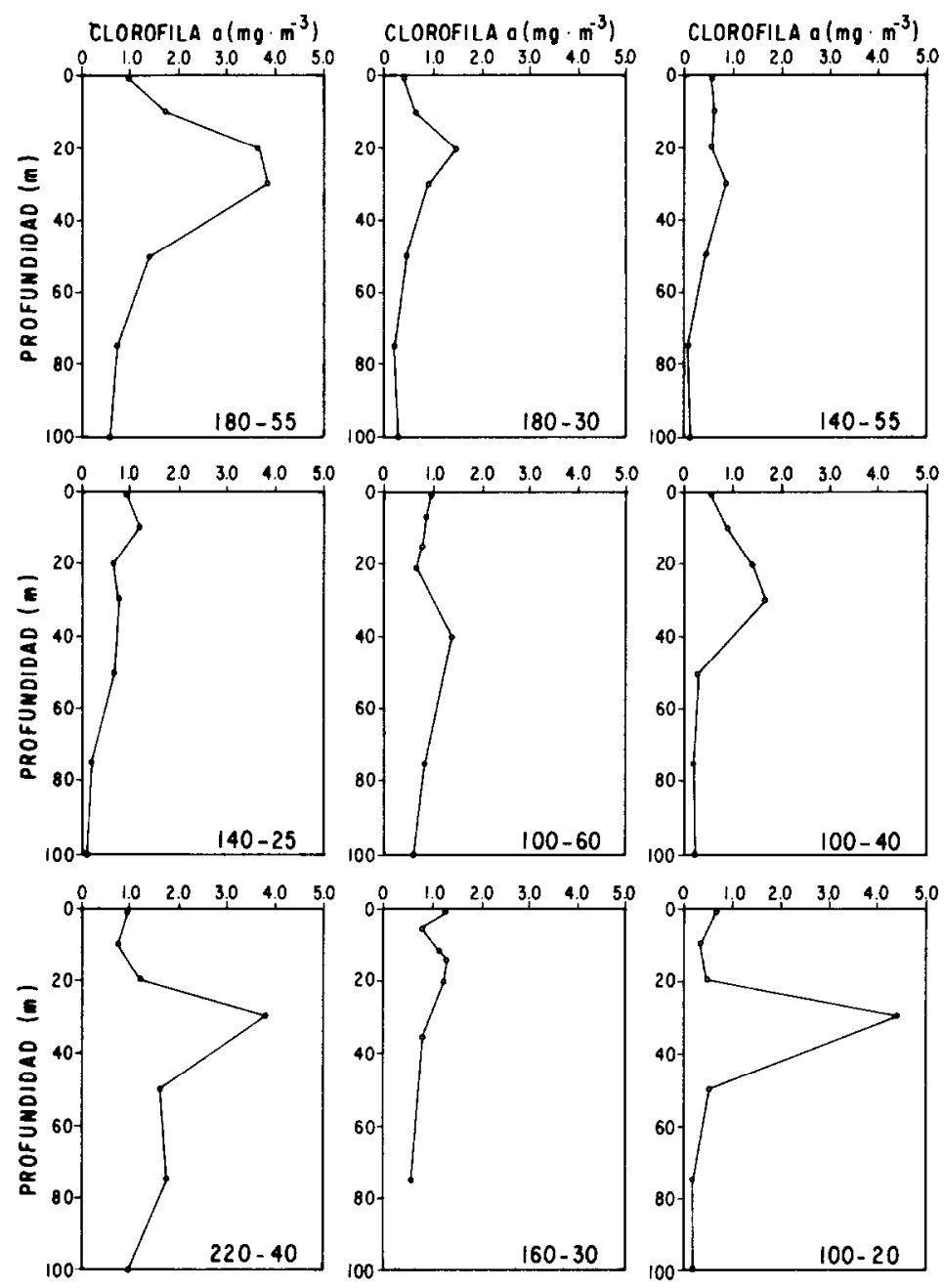

Figura 3. Continuación.

Figure 3. Continued.

$\left.0.035 \mathrm{~m}^{2}[\mathrm{gCla}]^{-1}\right)$. Sin embargo, los valores estimados de productividad primaria para la primavera en el golfo, a partir del valor propuesto por Morel (1978), sobreestiman hasta por $100 \%$ el valor obtenido con el método del ${ }^{14} \mathrm{C}$ (estaciones 340-65, 300-80, 220-57 y 100-60) (tabla 1). El valor de productividad integrada estimado para la estación $160-30$ subestima el del medido con el del ${ }^{14} \mathrm{C}$ por un $60 \%$. Las estimaciones de la productividad con los valores de
Gulf of California, shows a uniform tendency in the entire study area, with exception to the region of the large islands, where the values were higher (table 1). The values of primary productivity obtained from the $\Psi^{*}{ }_{\text {tot }}$ parameter range from $0.49 \mathrm{gC} \mathrm{m}^{-2} \mathrm{~d}^{-1}$ in the southern region (station $340-65$ ) to $1.30 \mathrm{gC} \mathrm{m}^{-2} \mathrm{~d}^{-1}$ in the large islands region (station 180-55) (table 1). The primary productivity estimates conducted with $\Psi_{p}^{*}$ are within an interval of values from 


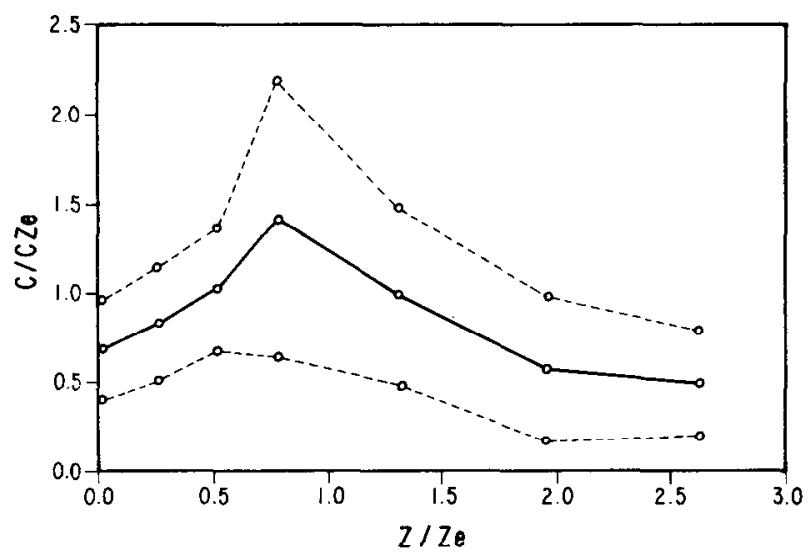

Figura 4. Perfil promedio de pigmentos, normalizado con respecto a la profundidad y concentración de pigmentos promedio en la zona eufótica. Las líneas discontinuas corresponden a una desviación estándar.

Figure 4. Mean profile of pigments normalized with respect to depth and to the mean concentration of pigments in the euphotic zone. The dashed lines correspond to one standard deviation.

este parámetro calculados con datos históricos del golfo de California, muestran una tendencia uniforme en toda el área de estudio, a excepción de la región de las grandes islas, donde los valores fueron mayores (tabla 1). Los valores de productividad primaria obtenidos a partir del parámetro $\Psi^{*}{ }_{\text {tot }}$ van de $0.49 \mathrm{gC} \mathrm{m}^{-2} \mathrm{~d}^{-1}$ en la región sur (estación 340-65) hasta $1.30 \mathrm{gC} \mathrm{m}^{-2} \mathrm{~d}^{-1}$ en las grandes islas (estación 180-55) (tabla 1). Las estimaciones de productividad primaria realizadas con $\Psi_{\mathrm{p}}^{*}$ están en un intervalo de valores de $0.40 \mathrm{gC} \mathrm{m}^{-2} \mathrm{~d}^{-1}$ en la parte sur (estación 340-65) hasta $1.06 \mathrm{gC} \mathrm{m}^{-2} \mathrm{~d}^{-1}$ en las grandes islas (estación 180-55). Los cálculos de productividad con estos valores se asemejan más a los valores medidos con el método del ${ }^{14} \mathrm{C}$. Las estimaciones con el parámetro $\Psi_{\text {tot }}^{*}$ están en un $60 \%$ de diferencia mientras que con $\Psi_{p}^{*}$ las diferencias son del $30 \%$. Sin embargo, en la región del canal de Ballenas (estación 160-30) el valor medido sobrepasa hasta tres veces a los estimados con $\Psi_{\text {tol }}^{*}$ y $\Psi_{\mathrm{p}}^{*}$.

\section{DISCUSIÓN}

Los valores de productividad primaria en cada profundidad obtenidos con el método del
$0.40 \mathrm{gC} \mathrm{m}^{-2} \mathrm{~d}^{-1}$ in the southern region (station $340-65$ ) up to $1.06 \mathrm{gC} \mathrm{m}^{-2} \mathrm{~d}^{-1}$ in the large islands (station 180-55). The productivity calculations made with these values are more comparable to the values measured with the ${ }^{14} \mathrm{C}$ method. The estimates using the $\Psi^{*}{ }_{\text {lot }}$ parameter are $60 \%$ different, while those using $\Psi_{p}^{*}$ are $30 \%$. However, in the Ballenas Channel region (station 160-30), the measured value is three times greater those estimated with $\Psi^{*}$ tot and $\Psi^{*}$.

\section{DISCUSSION}

At every depth, the values of primary productivity obtained with the ${ }^{14} \mathrm{C}$ method and the estimates using natural fluorescence, in general, do not differ much in all of the cases. The high correlation coefficient between the methods demonstrates that the primary productivity estimates made with natural fluorescence are consistent with in situ data measured with ${ }^{14} \mathrm{C}$. The estimates using natural fluorescence, however, should be calibrated with a greater number of field data, since the parameters on which these are based constitute the quantum efficiencies ratio of fluorescence and productivity (equal to one constant, $\mathrm{EQ}=2.4$ ) (Chamberlin et al., 
${ }^{14} \mathrm{C}$ y las estimaciones con la fluorescencia natural no difieren mucho en todos los casos. El alto coeticiente de correlación entre los métodos demuestra que las estimaciones de productividad primaria hechas a partir de fluorescencia natural son consistentes con datos in situ medidos con ${ }^{14} \mathrm{C}$. Aunque estas estimaciones a partir de la fluorescencia natural deben ser calibradas con mayor cantidad de datos de campo, ya que los parámetros en que éstas se basan son la razón de las eficiencias cuánticas para fluorescencia y productividad (igual a una constante, $\mathrm{EQ}=2.4$ ) (Chamberlin et al.,1990), la cual se considera como una función directa y lineal de la irradiancia. Cullen y Lewis (1992) hacen notar que esta relación es válida únicamente para irradiancias bajas (abajo de la irradiancia de saturación). Cerca de la superficie, la dispersión de la luz hacia atrás y el pobre conocimiento de los cambios del campo de la fluorescencia complican la estimación de la clorofila y productividad a partir de la radiancia ascendente a $683 \mathrm{~nm}$ (fluorescencia natural). Una característica común en todos los perfiles de productividad estimada con fluorescencia natural fue la persistencia de valores altos en superficie. Esto puede estar asociado a la alta proporción de luz solar de $683 \mathrm{~nm}$ que se encuentra a esa profundidad y satura el sensor de radiancia. Sin información adicional, es dificil conocer hasta qué profundidad es significativa la dispersión hacia atrás de la irradiancia descendente de $683 \mathrm{~nm}$, por lo que la relación de productividad y fluorescencia natural es incierta para fitoplancton superficial (Cullen y Lewis, 1992).

La productividad integrada estimada a partir de la fluorescencia natural difiere en algunas ocasiones hasta en un $90 \%$ de las realizadas con el método del ${ }^{14} \mathrm{C}$. Sin embargo, para los muestreos hechos temprano en la mañana o al atardecer fueron evidentes valores altos de la productividad estimada de la fluorescencia natural, posiblemente asociados a la irradiancia in situ y la extrapolación de la productividad para todo el día. La proporción de luz de cielo aumenta en relación a la luz directa con el aumento del ángulo de incidencia de la irradiancia (Kirk, 1983), por lo que se presentan bajas irradiancias asociadas con alta fluorescencia
1990), which is considered to be a direct and linear function of irradiance. Cullen and Lewis (1992) note that this equation is valid only at low irradiances (lower than that of saturation irradiance). The backscattering of solar light near the surface and the little knowledge of the changes in the field of fluorescence complicate the estimation of chlorophyll and productivity using an upwelling radiance of $683 \mathrm{~nm}$ (natural fluorescence). A common characteristic in all of the productivity profiles estimated from natural fluorescence was the persistence of high values in the surface. This can be associated with the high proportion, $683 \mathrm{~nm}$, of solar light that is found at this depth and saturates the radiance sensor. Without additional information, it is difficult to know up to what depth the backscattering of the downwelling irradiance of $683 \mathrm{~nm}$ is significant. This causes uncertainties in the relationship between productivity and natural fluorescence for surface phytoplankton (Cullen and Lewis, 1992).

The integrated productivity estimated from natural fluorescence differs, on some occasions, by up to $90 \%$ from those conducted with the ${ }^{14} \mathrm{C}$ method. However, the samplings conducted early in the morning or at dusk presented high values of productivity estimated from natural fluorescence. These were possibly associated with the in situ irradiance and the extrapolation of productivity for the entire day. The proportion of sky light increases in relation to direct light with the increase in the incidence angle of irradiance (Kirk, 1983), thus presenting low irradiances, associated with high natural tluorescence (radiance at $683 \mathrm{~nm}$ ). Also, given that the empirical equation of Chamberlin et al. (1990) is a direct and linear function of irradiance and biomass, significant estimates of productivity are obtained under conditions of low irradiance. Upon extrapolating the calculated productivity in the water column to the entire day, this high productivity with low irradiance increases greatly if it is related to the total irradiance for the entire day (table 1).

The surface chlorophyll and vertical attenuation coefficient of diffused light $\left(\mathrm{K}_{d}\right)$ were correlated $\left(\mathrm{K}_{\mathrm{d}}=0.072+0.036 \mathrm{Cl} a, \mathrm{r}=0.69\right.$, $n=48$ ) which explains approximately $50 \%$ of 
natural (radiancia a $683 \mathrm{~nm}$ ), y dado que la relación empírica de Chamberlin et al. (1990) es función directa y lineal de la irradiancia y de la biomasa, se tienen estimaciones significativas de productividad en condiciones de baja irradiancia. Al extrapolar la productividad calculada de la columna de agua para todo el dia, esta alta productividad con baja irradiancia aumenta en gran medida si se relaciona con la irradiancia total para todo el día (tabla 1 ).

La clorofila superficial y el coeficiente de atenuación vertical de luz difusa $\left(\mathrm{K}_{\mathrm{d}}\right)$ fueron correlacionados $\left(\mathrm{K}_{\mathrm{d}}=0.072+0.036 \mathrm{Cla}, \mathrm{r}=\right.$ $0.69, \mathrm{n}=48$ ), por lo que aproximadamente el $50 \%$ de varianza de la profundidad de la zona eufótica está explicada por la concentración de pigmentos. Otro porcentaje de la varianza podría estar asociado a errores en la estimación de la profundidad real de la muestra de clorofila con relación a la profundidad del cálculo de $K_{d}$. Bajo esta suposición, es posible establecer la relación entre clorofila superficial y clorofila integrada en la zona eufótica $\langle\mathrm{C}\rangle_{\text {tot }}=25.96+$ 15.55 C, $r=0.56, n=20$, y entre la clorofila en la primera profundidad óptica y clorofila integrada en la zona eufótica $\langle\mathrm{C}\rangle_{\text {tot }}=21.8+$ $2.06 \overline{\mathrm{C}}_{\mathrm{pd}}, \mathrm{r}=0.75, \mathrm{n}=20$. Estas correlaciones son similares a las reportadas por CervantesDuarte et al. (1993) para un crucero durante el invierno de 1990. La mayor correlación entre la clorofila de la primera profundidad óptica y la integrada se debe a que en ésta se incluye una mayor información de la columna de agua (entre $1 / 5$ y $1 / 10$ ) que con la clorofila superficial (Morel y André, 1991). Bajo el criterio de Morel y Berthon (1989), la situación trófica del golfo de California durante la primavera es de aguas mesotróficas. Cervantes-Duarte et al. (1993) concluyeron que para el invierno la situación trófica del golfo también es mesotrófica, con valores promedio de biomasa superficial de $1.39 \mathrm{mg} \mathrm{m}^{-3} \mathrm{e}$ integrada de $49.17 \mathrm{mg} \mathrm{m}^{-2}$. El perfil promedio de biomasa del golfo de California para esta estación del año muestra un máximo profundo aproximadamente al $10 \%$ de $E_{0}$ (fig. 4). Una vez conocida la biomasa superficial a partir de sensores remotos (aproximadamente una profundidad óptica), es posible relacionarla con la biomasa integrada en la zona the variance in depth of the euphotic zone by the concentration of pigments. Another percentage of the variance could be associated with errors in estimating the true depth of the chlorophyll sample related to the depth of the $K_{d}$ calculation. Under this assumption, it is possible to establish the relationship between surface chlorophyll and integrated chlorophyll in the euphotic zone $\langle\mathrm{C}\rangle_{\text {lot }}=25.96+15.55 \mathrm{C}, \mathrm{r}=$ $0.56, \mathrm{n}=20$, and between chlorophyll in the first optical depth and integrated chlorophyll in the euphotic zone $\langle\mathrm{C}\rangle_{\text {tot }}=21.8+2.06 \overline{\mathrm{C}}_{\mathrm{pd}}, \mathrm{r}=$ $0.75, \mathrm{n}=20$. The correlations are similar to those reported by Cervantes-Duarte et al. (1993) from a cruise conducted in the winter of 1990. The greater correlation between chlorophyll in the first optical depth and integrated is due to the fact that more information is included from the water column (between 1/5 and 1/10) than from surface chlorophyll (Morel and André, 1991). Under the criterion of Morel and Berthon (1989), the trophic situation in the Gulf of California during spring consists of mesotrophic waters. Cervantes-Duarte et al. (1993) also concluded that the trophic situation in the gulf in winter is mesotrophic, with mean values of surface biomass of $1.39 \mathrm{mg} \mathrm{m}^{-3}$ and integrated of $49.17 \mathrm{mg} \mathrm{m}^{-2}$. The mean profile of biomass in the Gulf of California for this season of the year shows a maximum depth of approximately $10 \% \mathrm{E}_{0}$ (fig. 4). Once the surface biomass is established by the remote sensors (approximately one optical depth), it is possible to relate it to the integrated biomass in the euphotic zone and calculate production in the water column using photosynthesis-irradiance models.

It has been estimated that the error introduced by calculating phytoplankton productivity from bio-optic models can be as much as $60 \%$ (Kyelwalyanga et al., 1992), and is associated with photosynthetic parameters directly related to light absorption processes (Rochet $e t$ al., 1986; Sathyendranath et al., 1989). Platt et al. (1991) have suggested the use of global averages for large oceanic areas. Morel (1978) proposes a $\Psi^{*}$ value of $0.07 \mathrm{~m}^{2}(\mathrm{Cla})^{-1}$, even though the values of daily primary productivity in the gulf estimated with this value overesti- 
cufótica y calcular la producción de la columna de agua a partir de modelos fotosíntesis-irradiancia.

Se ha estimado que el error involucrado para calcular la productividad del fitoplancton mediante modelos bioópticos puede ser de hasta un 60\% (Kyelwalyanga et al., 1992), y está asociado a los parámetros de la fotosíntesis directamente relacionados con los procesos de absorción de luz (Rochet et al., 1986; Sathyendranath et al., 1989). Para grandes áreas oceánicas se ha sugerido el uso de promedios globales (Platt et al., 1991). Morel (1978) propone un valor de $\Psi^{*}$ de $0.07 \mathrm{~m}^{2}(\mathrm{Cla})^{-1}$, aunque los valores estimados de productividad primaria diaria para el golfo utilizando este valor sobreestiman por un $100 \%$ el valor medido. Las estimaciones de la productividad con los valores de este parámetro calculado con datos históricos se asemejan más a los valores medidos.

Los valores estimados de productividad muestran una tendencia uniforme en todo el golfo de California, a excepción de la región de las grandes islas donde los valores fueron mayores. La productividad primaria medida con el método del ${ }^{14} \mathrm{C}$ fue mayor en canal de Ballenas, mientras que la productividad estimada con la fluorescencia natural fue muy variable en función de la hora del muestreo, como se explicó al principio, sin embargo, para los muestreos alrededor del mediodia siguió la misma tendencia.

La estimación de la productividad de la columna de agua con el parámetro obtenido para primavera, da valores más cercanos a los medidos, ya sea con el método de ${ }^{14} \mathrm{C}$ o fluorescencia natural, aunque su utilización debe tomarse con cautela en áreas donde existe una fuerte mezcla, como el canal de Ballenas. Morel (1991) menciona que escoger un parámetro fisiológico como $\Psi^{*}$ es más flexible, ya que estos parámetros están menos documentados que los físicos. En este sentido, es más aceptable el valor de $\Psi^{*}$ estimado para primavera que el total y el propuesto por Morel (1978). Es recomendable obtener un valor de $\Psi^{*}$ por estación del año y por regiones, dada la gran variabilidad hidrográfica del golfo de California. Sin embargo, la información disponible actualmente no permite realizar una regionalización o estacionalidad de di- mate the mean value by $100 \%$. The productivity estimates using values of this parameter calculated with historical data are more similar to the mean values.

The estimated values of productivity show a uniform tendency in the entire Gulf of California, with exception to the region of the large islands, where the values were greater. Primary productivity measured with the ${ }^{14} \mathrm{C}$ method in Ballenas Channel was greater, while productivity estimated from natural fluorescence was highly variable with respect to the hour of the sampling, as explained at the beginning; however, in the samplings around noon, the same tendency was followed.

The estimate of productivity in the water column using the parameter obtained for spring, gives values closer to the means, with either the ${ }^{14} \mathrm{C}$ or natural fluorescence method, although it should be used carefully in areas where there is a strong mixing, such as in Ballenas Channel. Morel (1991) mentions that choosing a physiological parameter such as $\Psi^{*}$ is more flexible, since these parameters are less documented than physical ones. In this sense, the $\Psi^{*}$ value estimated for spring is more acceptable than the total and that proposed by Morel (1978). It is recommended to obtain a $\Psi^{*}$ value for each season of the year and for each region, given the hydrographic variability in the Gulf of California. However, the information available at present does not allow for a separation of geographic areas (regionalization) or seasonality of said parameter, since the data on primary productivity do not present spatial or temporal regularity, nor do they include irradiance data for conducting estimates of the parameter.

\section{ACKNOWLEDGEMENTS}

This study was financed by the Programa Nacional de Pelágicos Menores of the Instituto Nacional de la Pesca (CRIP-Guaymas) under the project Relación Recurso-Medio Ambiente. The collaboration of the crew from $B I P-X I$ was valuable. We thank Antonio Cruz, Ramón Barraza and Isidro Vázquez for their support. The comments by Saúl Álvarez-Borrego and an anonymous reviewer significantly improved the 
cho parámetro. ya que los datos de productividad primaria no presentan regularidad espacial y temporal, o bien la información no incluye datos de irradiancia para llevar a cabo las estimaciones del parámetro.

\section{AGRADECIMIENTOS}

Este trabajo fue financiado por el Programa Nacional de Pelágicos Menores del Instituto Nacional de la Pesca (CRIP-Guaymas), bajo el proyecto Relación Recurso-Medio Ambiente. La colaboración de la tripulación del $B I P-X I$ fue valiosa. Agradecemos el apoyo de Antonio Cruz, Ramón Barraza e Isidro Vázquez. Los comentarios de Saúl Álvarez-Borrego y un revisor anónimo mejoraron sustancialmente este trabajo. El primero y último autor recibieron del Consejo Nacional de Ciencia y Tecnología una beca durante su estancia en el Centro de Investigación Científica y de Educación Superior de Ensenada.

\section{REFERENCIAS}

Álvarez-Borrego, S. and Gaxiola-Castro, G. (1988). Photosynthetic parameters of northern Gulf of California phytoplankton. Continental Shelf Research, 8: 37-47.

Álvarez-Borrego, S. and Lara-Lara, J.R. (1991). The physical environment and primary productivity of the Gulf of California. In: J.P. Dauphin and B. Simoneit (eds.), The Gulf of California and Peninsular Province of the Californias. American Association of Petroleum Geologists, Memoir, 47: 555-567.

Cervantes-Duarte, R., Gaxiola-Castro, G. y Valdez-Holguín, J.E. (1993). Relación entre clorofila superficial y clorofila en la zona eufótica del golfo de California: Posible aplicación para estimar la producción primaria con datos obtenidos por sensores remotos. Ciencias Marinas, 19(4): 473-490.

Chamberlin, W.S., Booth, C.R., Morrow, J.R. and Murphy, R.C. (1990). Evidence for a simple relationship between natural fluorescence, photosynthesis and chloro- manuscript. The first and last author received a grant from Consejo Nacional de Ciencia $y$ Tecnologia during their stay at the Centro de Investigación Cientifica y de Educación Superior de Ensenada.

English translation by Jennifer Davis.

phyll in the sea. Deep Sea Res.. 37: 951-973.

Cleveland, J.S., Perry, M.J., Kiefer D.A. and Talbot M.C. (1989). Maximal quantum yield of photosynthesis in the northwestern Sargasso Sea. J. Marine Research, 47: 869-886.

Cullen, I.J. and Lewis, M.R. (1992). Strategies for using in situ optical and biological measurements to complement remote sensing. Autonomous Bio-Optical Ocean Observing Systems Scientific Symposium. April 6-10, Monterey, CA, extended abstract.

Gaxiola-Castro, G. y Álvarez-Borrego, S. (1986). Productividad primaria del Pacífico mexicano. Ciencias Marinas, 12(3): 26-33.

Kirk, J.T.O. (1983). Light and Photosynthesis in Aquatic Ecosystems. Cambridge, $401 \mathrm{pp}$.

Kyelwalyanga, M., Platt, T. and Sathyendranath, S. (1992). Ocean primary production calculated by spectral and broad-band models. Mar. Ecol. Prog. Ser., 85: 171-185.

Lara-Lara, I.R. y Valdez-Holguín, J.E. (1988). Biomasa y productividad primaria del golfo de California por fracciones de tamaños durante primavera de 1984. Ciencias Marinas, $14(1): 1-14$.

Lewis, M.R., Warnock, R.E. and Platt, T. (1985). Absorption and photosynthetic action spectra for natural phytoplankton populations: Implications for production in the open ocean. Limnol. Oceanogr., 30(4): 794-806.

Morel, A. (1978). Available, usable and stored radiant energy in relation to marine photosynthesis. Deep Sea Res., 25: 673-688. 
Morel, A. (1991). Light and marine photosynthesis: $A$ spectral model with geochemical and climatological implications. Progress in Oceanography, 25: 263-306.

Morel A. and Berthon, J.F. (1989). Surface pigments, algal biomass profiles, and potential production of the euphotic layer: Relationships reinvestigated in view of remote-sensing applications. Limnol. Oceanogr., 34: 1545-1562.

Morel, A. and André, J.M. (1991). Pigment distribution and primary production in the western Mediterranean as derived and modeled from coastal color zone scanner observations. J. Geophys. Res., 96: 12,685-12,698.

Parsons, T.R., Maita, Y. and Lalli, C.M. (1984). A Manual of Chemical and Biological Methods for Seawater Analysis. Pergamon Press, Oxford, $173 \mathrm{pp}$.

Parsons, T.R. and Strickland, J.D.H. (1963). Discussion of spectrophotometric determination of marine plant pigments, with revised equations for ascertaining chlorophylls and carotenoids. J. Mar. Res., 21: 155-163.

Platt, T. (1986). Primary production of the ocean water column as a function of surface light intensity: algorithms for remote sensing. Deep Sea Res., 33: 149-163.

Platt, T. and Jassby, A.D. (1976). The relationship between phtosynthesis and light for natural assemblages of coastal marine phytoplankton. J. Phycol., 12: 421-430.

Platt, T. and Sathyendranath, S. (1993). Estimators of primary production for interpretation of remotely sensed data on ocean color. J. Geophys. Res., 98(C8): 14,56114,576 .

Platt, T., Sathyendranath, S. and Ravindran, P. (1990). Primary production by phytoplankton: Analytic solutions for daily rates per unit area of water surface. Proc. R. Soc. London, Ser. B., 241: 101-111.

Platt, T., Caverhill, C.M. and Sathyendranath, S. (1991). Basin-scale estimates of primary production by remote sensing: The North Atlantic. J. Geophys. Res., 96(C8): 15,147-15,159.

Rochet, M., Legendre, $\mathbf{L}$. and Demers, S. (1986). Photosynthetic and pigment responses of sea-ice microalgae to changes in light intensity and quality. J. Exp. Mar. Biol. Ecol., 101: 211-226.

Round, F.E. (1967). The phytoplankton of Gulf of California. Part I. Its composition, distribution and contribution to the sediments. J. Exp. Mar. Biol. Ecol., 1:76-97.

Ryther, J.H. (1956). Photosynthesis in the ocean as a function of light intensity. Limnol. Oceanogr., I: 61-70.

Sathyendranath, S., Platt, T., Caverhill, C.M., Warnock, R.E. and Lewis, M.R. (1989). Remote sensing of oceanic primary production: Computations using spectral model. Deep Sea Res., 36: 431-453.

Steemann Nielsen, E. (1952). The use of radioactive carbon $\left({ }^{14} \mathrm{C}\right)$ for measuring organic production in the sea. J. Cons. Per. Int. Explor. Mer., 18: 117-140.

Talling, J.F. (1957). The phytoplankton population as a compound photosynthetic system. New Phytol., 56: 133-149.

Valdez-Holguín, J.E. y Lara-Lara, J.R. (1987). Productividad primaria en el golfo de California: Efectos del evento El Niño 1982-1983. Ciencias Marinas, 13(2): 34-50.

Venrick, F and Hayward, T (1984). Determining chlorophyll on the 1984 CALCOFI surveys. CALCOFI Rep., 25: 74-79.

Zeitzschel, B. (1969). Primary productivity in the Gulf of California. Mar. Biol., 3: 201-207. 